2015-09-15

Testing the resilience of dead maerl infaunal assemblages to the experimental removal and re-lay of habitat

Sheehan, Emma

http://hdl.handle.net/10026.1/9139

10.3354/meps 11400

Marine Ecology Progress Series

Inter-Research Science Center

All content in PEARL is protected by copyright law. Author manuscripts are made available in accordance with publisher policies. Please cite only the published version using the details provided on the item record or document. In the absence of an open licence (e.g. Creative Commons), permissions for further reuse of content should be sought from the publisher or author. 


\begin{tabular}{c|c|c}
\hline \hline $\begin{array}{c}\text { Vol. 535: 117-128, 2015 } \\
\text { doi: } 10.3354 / \text { meps11400 }\end{array}$ & $\begin{array}{c}\text { MARINE ECOLOGY PROGRESS SERIES } \\
\text { Mar Ecol Prog Ser }\end{array}$ & Published September 15 \\
\hline
\end{tabular}

\title{
Testing the resilience of dead maerl infaunal assemblages to the experimental removal and re-lay of habitat
}

\author{
Emma V. Sheehan, Danielle Bridger, Sophie L. Cousens, Martin J. Attrill* \\ Marine Institute, Plymouth University, Drake Circus, Plymouth PL4 8AA, UK
}

\begin{abstract}
An experimental trial to mitigate dredging impact was undertaken within Falmouth Harbour, UK, removing a surface layer of dead maerl for storage on a barge and allowing the channel to be deepened before re-laying the maerl. The resilience (resistance and recovery) of the habitat and faunal assemblage to this disturbance was assessed. Six sites each had 2 conditions a manipulated treatment area where maerl $\left(25 \mathrm{~m}^{2}\right.$ plots, top $\left.0.3 \mathrm{~m}\right)$ was removed, stored on a barge and re-laid by backhoe dredger and a control area - which were cored at 0 (before), 5 and 44 wk after re-lay. PERMANOVA was used to test for differences between condition and time using a 2-factor design. Results should not be extrapolated to live maerl habitats or to large, longlived fauna that may live within them. Following the mechanical disturbance, the maerl matrix structure was altered through loss of fine sediment from the lower half of cores $(>10 \mathrm{~cm})$. There was also a significant reduction in the number of taxa and abundance of infauna and a change in the assemblage composition. By Week 44, however, no such significant differences were evident, indicating that the infauna was in a state of recovery. The only response variable showing recovery was annelid biomass. The trial demonstrated that removing and re-laying the top $0.3 \mathrm{~m}$ of maerl habitat is technically feasible, and whilst some differences in the habitat structure following re-laying were evident, this did not affect the habitat quality enough to prevent recolonisation of infauna.
\end{abstract}

KEY WORDS: Marine protected area - Recovery - Anthropogenic impact - Ecosystem impact · Dredging mitigation $\cdot$ Marine biodiversity $\cdot$ Habitat complexity Resale or republication not permitted without written consent of the publisher

\section{INTRODUCTION}

Maerl is a term for unattached coralline red algae which form beds that comprise live and/or dead thalli at depths up to $40 \mathrm{~m}$ (OSPAR 2010). Maerl beds are biogenic, structurally complex habitats (Hall-Spencer 1998) and are thus analogous to temperate seagrass beds or kelp forests (BIOMAERL Team 1999) in that they support a rich biodiversity (Barbera et al. 2003, Peña et al. 2014), including molluscs (Hall-Spencer 1998), crustaceans and annelids (Bosence 1979, Barbera et al. 2003). They also act as nursery grounds for commercially important species of fish, crabs and bivalve molluscs such as the queen scallop Aequi- pecten opercularis (L.) (Hall-Spencer 1998, Kamenos et al. 2004a,b). Whilst the vast majority of studies have focussed on the value of live maerl beds, the dead calcareous skeletons of maerl also form a structurally complex and important habitat, but have rarely been studied. Generally, dead maerl has been considered to be of a lower diversity and structural value than live maerl (e.g. Nunn 1992, Kamenos et al. 2003); however, meiofaunal bivalves have been found in greater abundances in the dead maerl matrix than live (Jackson et al. 2004), and a recent comparison of maerl epifauna has shown that the relative importance of dead and live maerl can vary with location (Sheehan et al. 2015). 
Maerl beds have a particularly high level of international conservation designation: they are a UK Biodiversity Plan Priority Habitat (UK Biodiversity Group 1999) and are protected under the European Habitats Directive (92/43/EEC $;$ Council of the European Union 1992), for example. Despite their ecological and economic importance, they are under threat from anthropogenic impacts, including extraction, offshore dumping and land reclamation (Barbera et al. 2003). In particular, live maerl appears to be highly intolerant of smothering, changes in suspended sediment and physical disturbance (Wilson et al. 2004). Hall-Spencer \& Moore (2000) investigated the impacts of scallop dredging on live maerl communities and found that dredging led to a $>70 \%$ reduction of live maerl thalli. Furthermore, no sign of live maerl recovery was found over $4 \mathrm{yr}$ of monitoring.

Falmouth Harbour, southwest England, falls within the Fal and Helford Estuaries Special Area of Conservation (SAC) under the EC Habitats Directive (92/43/EEC; Council of the European Union 1992). Maerl beds comprising mostly dead maerl with some live fragments (Fig. 1) occur in a part of the estuary where a dredging proposal to deepen the shipping channel has been put forward. Dredging of harbours and docks to maintain access can induce extreme environmental changes and may significantly alter ecological pathways (De Grave \& Whitaker 1999). Over time, impacted communities may return to predredge abundance levels, but the habitat structure and integrity may never recover (McCauley et al. 1977). The dredging and deposition of sediment can immediately smother and bury benthic fauna (Cooper et al. 2005). Dredging can also homogenise seafloors and change the habitat from coarse sediments to finer sands, altering the benthic assemblage (Thrush \& Dayton 2002, Cooper et al. 2005). De Grave \& Whitaker

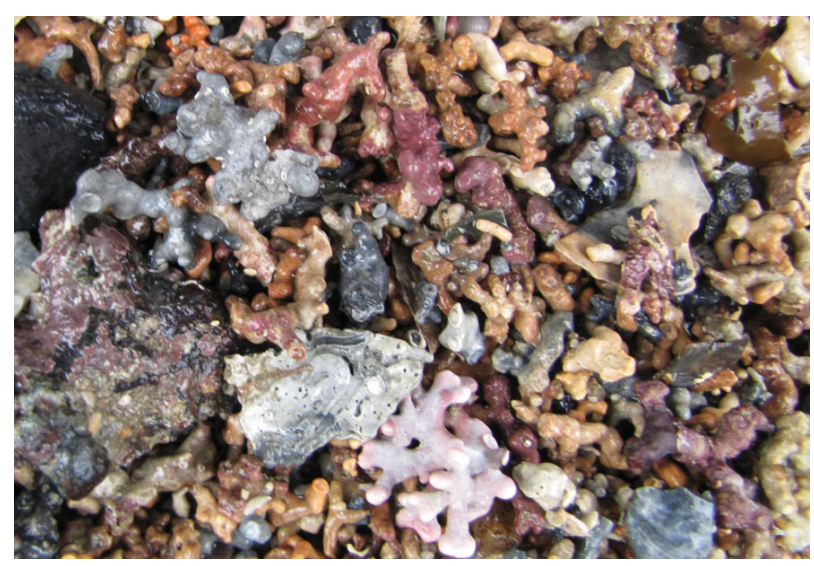

Fig. 1. Example of maerl habitat found in Falmouth Harbour
(1999) found that benthic infauna at a dredged site with a muddy-maerl sediment matrix exhibited higher levels of stress than the control site. Furthermore, there was a higher abundance of omnivorous crustaceans in the dredged treatment plots compared to the higher abundance of filter-feeding bivalves in the controls. This was thought to be as a result of the relative instability of the sediment and the increased turbidity due to dredging operations. Dredging Falmouth Harbour could therefore impact the dead maerl habitat within the proposed dredge zone, the live maerl in adjacent areas and/or the associated benthic infauna (Deeble \& Stone 1985, Hall-Spencer \& Moore 2000).

In order to deepen the channel without compromising the integrity of the dead maerl beds and the associated infaunal communities, it was suggested that the surface layer of maerl could be temporarily removed and held, the channel deepened and the sensitive, protected habitat re-laid from where it was taken. To test the feasibility of this proposal, a trial was undertaken to assess whether the maerl habitat and its associated assemblage was sufficiently resilient to withstand the disturbance of being removed from the seabed, held on a barge and re-laid. If successful, the additional effects of deepening the channel could then be considered. A proposal was therefore put forward to mechanically excavate the top layer of the maerl (primarily dead maerl matrix in this part of the Fal; Sheehan et al. 2012), store it on a barge and re-lay it back in its original position.

Habitat translocation is the process of moving substrata and associated animals and vegetation to rescue habitats that would otherwise be lost due to, for example, changes in land use (Anderson 2003). Hodgson (1989) documented the key issues in habitat translocation: (1) minimising damage to the principal species involved, (2) the re-establishment of fauna and flora in the receptor site and (3) the provision of suitable after-care in order to minimise loss of value or scientific interest. Box (2003) noted the lack of systematic evaluation and documentation in existing projects involving habitat translocation, which has resulted in few successful establishments of sustainable populations (Sheller et al. 2006); fewer than half of 421 translocation efforts surveyed by Griffith et al. (1989) and Wolf et al. (1996) were successful. No data exist, however, on the recovery of translocated maerl beds, although assessments on the ecological consequences of disposing of dredged material show that those communities within impacted sites generally have poorer fauna abundance (Bolam et al. 2006). 
We undertook a novel experimental trial to assess whether a valuable benthic habitat and associated infaunal assemblage was sufficiently resilient to be removed, stored and re-laid back onto the seabed. Two components of resilience (Kotta et al. 2008) were tested, resistance to disturbance and recovery from disturbance, using a suite of habitat (mean particle size, maerl matrix structure, organic content) and faunal (number of taxa, abundance, key phylum biomass, assemblage composition) response variables.

\section{MATERIALS AND METHODS}

\section{Study area and experimental design}

Falmouth Harbour (Fig. 2a), located in southwest England is a sheltered site, which hosts large maerl beds (OSPAR 2010). The study location comprises mostly dead maerl beds, with smaller patches containing live maerl fragments, particularly to the south of the planned dredge area (Sheehan et al. 2012). The tidal range is $\sim 6 \mathrm{~m}$. The experimental design included 6 sites: 5 dead maerl sites (Sites 1-5) and 1 site where live maerl fragments were scattered across the dead maerl matrix surface (Site 6) (Fig. 2a). These were selected from a geo-referenced towed high-definition video survey (Sheehan et al. 2010) undertaken in November 2011 and February 2012. All sites were located at depths between 4 and $7 \mathrm{~m}$ below chart datum. Each site contained 2 conditions located a minimum of $20 \mathrm{~m}$ apart (Fig. 2b): a manipu- lated treatment area where the maerl was excavated and re-laid, and a control area. Each condition was subdivided into three $5 \mathrm{~m}^{2}$ plots. Each plot was used at only 1 sampling time: Week 0 (baseline before maerl excavation and re-lay), Week 5 (5 wk after maerl re-lay) to assess resistance to disturbance and Week 44 (44 wk after maerl re-lay) to assess recovery from disturbance. This ensured that the 3 time points were independent from each other (Fig. 2b).

\section{Maerl extraction and re-lay}

The maerl was extracted and re-laid between 24 and 27 September 2012 under the jurisdiction of Falmouth Harbour Commissioners. The top $0.3 \mathrm{~m}$ of maerl was removed from the $5 \mathrm{~m}^{2}$ treatment plots at all 6 sites for Week 5 and Week 44 using a backhoe dredger (Figs. 2b \& 3a). The backhoe dredger was operated from a multipurpose dredging pontoon 'GPS Arnaud Regis' which was kept stable using spud legs. The maerl was deposited into a bespokedesigned barge that was held alongside the dredging pontoon; the barge and dredging pontoon were powered and positioned using a tug 'Zeepia' (Fig. 3a). Accurate positioning was achieved using differential GPS and 'Hypack' digital dredge system (provided by Del Norte Technologies) on the backhoe dredger. In conjunction with this, a real-time kinematic (RTK) base station was set up to monitor and automatically adjust the equipment to allow for the rise and fall of the tides and enable precision to $2 \mathrm{~cm}$ accuracy. a)

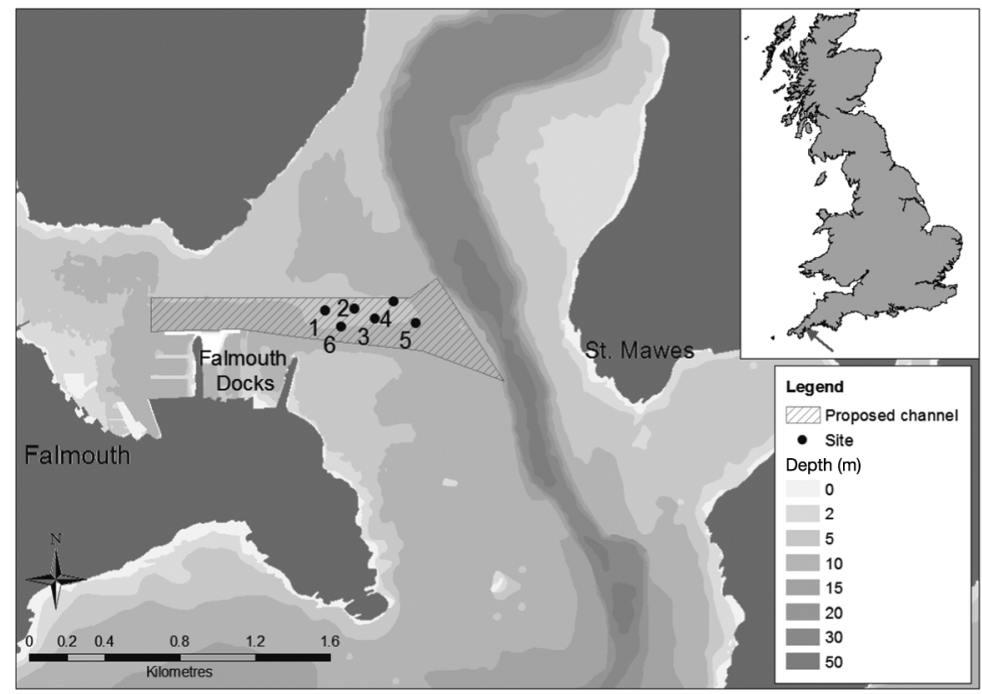

b)

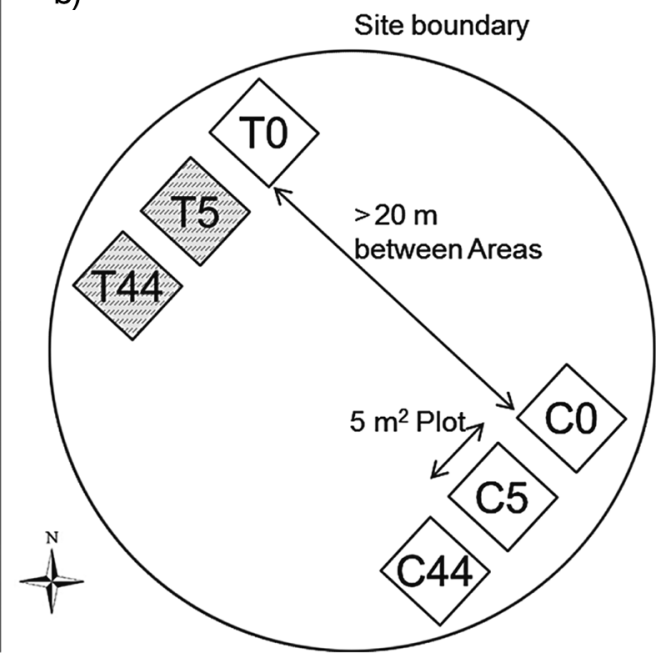

Fig. 2. (a) Falmouth Harbour, with locations of Sites 1-6 within the proposed dredge channel. (b) Diagram of treatment area (T), control area (C) and plot per site. Numbers indicate weeks from trial dredge: 0 (before dredge), 5 and 44 wk after trial dredge. Shading indicates plots which were dredged and re-laid. Eight cores were taken per plot ( 5 cores for infauna and 3 for habitat response variables) 
The maerl was stored in separate compartments for each $5 \times 5 \times 0.3 \mathrm{~m}$ plot on the barge in approximately $1 \mathrm{~m}$ deep sections for $12 \mathrm{~h}$ (Fig. 3b). This represented the amount of time that the maerl would be stored before it was re-laid in the proposed capital dredge scenario. Sections were created using purpose-built plywood inserts. Seawater was pumped over the stored maerl to provide survivable conditions for any living maerl fragments and the associated fauna.

After $12 \mathrm{~h}$, the maerl was returned to the excavated plot from where it had been extracted leaving a $5 \times 5$ $\times 0.3 \mathrm{~m}$ hole. The backhoe dredger removed the maerl from the barge and, guided by the dredge control software, re-laid the maerl into the hole so that it was level with the surrounding habitat. SCUBA divers then confirmed that the plot had been refilled and marked the centre with a $1 \mathrm{~m}$ steel eye-bolt (Fig. 3c). Floating rope and fishing floats were attached to ensure that plots could be found and sampled in Weeks 5 and 44. The first re-lay involved locating a $5 \times 5 \mathrm{~m}$ steel frame (Fig. 3d) that ensured perfect redeployment of the maerl. However, it inhibited the ability of the dredgers to re-lay the maerl accurately and so, once the method of re-laying had been proved and checked by SCUBA divers and on-board scientific team members through the live video communications attached to the diver, the relocation proceeded without the steel frame. sea surface temperature: $16.2^{\circ} \mathrm{C}_{\text {; }}$ mean salinity: 33.8$)$, Week 5 sampling from 30 October to 1 November 2012 (mean sea surface temperature: $12.9^{\circ} \mathrm{C}$; mean salinity: 33.7) and Week 44 sampling from 30 July to 1 August 2013 (mean sea surface temperature: $17.6^{\circ} \mathrm{C}$; mean salinity: 34.6). Sampling was carried out from the boat 'Pendennis'.

SCUBA divers (Falmouth Divers, linked to the surface by live communications so instructions could be given) collected 8 maerl core samples per plot: 5 cores for faunal analysis and 3 cores for sediment and organic content analysis. The pre-defined, randomly selected position of each core was located using a compass and line. A bespoke corer (Fig. 3e) was designed in order to sample dead maerl that is tightly packed and difficult to core. The corers were made from stainless steel (length: $25 \mathrm{~cm}$, diameter: $10 \mathrm{~cm}$ ), with retractable jaws to hold the sample intact. Cores were inserted when the jaws were open, sponge bungs positioned into each end of the core and the jaws were then closed by pushing down the side handles. The fauna cores were stored in bags and fixed in $10 \%$ boraxbuffered formalin. The sediment cores were split between 2 bags and frozen. The top half of the core $(\sim 0-10 \mathrm{~cm})$ was put into one bag and the bottom half $(\sim 11-25 \mathrm{~cm})$ into a second bag to be analysed separately.

\section{Sample collection}

\section{Habitat sample processing}

Week 0 sampling was carried out a week before the trial dredge from 12 to 14 September 2012 (mean

Samples were thawed prior to processing and a subsample was taken for each of the following analyses.
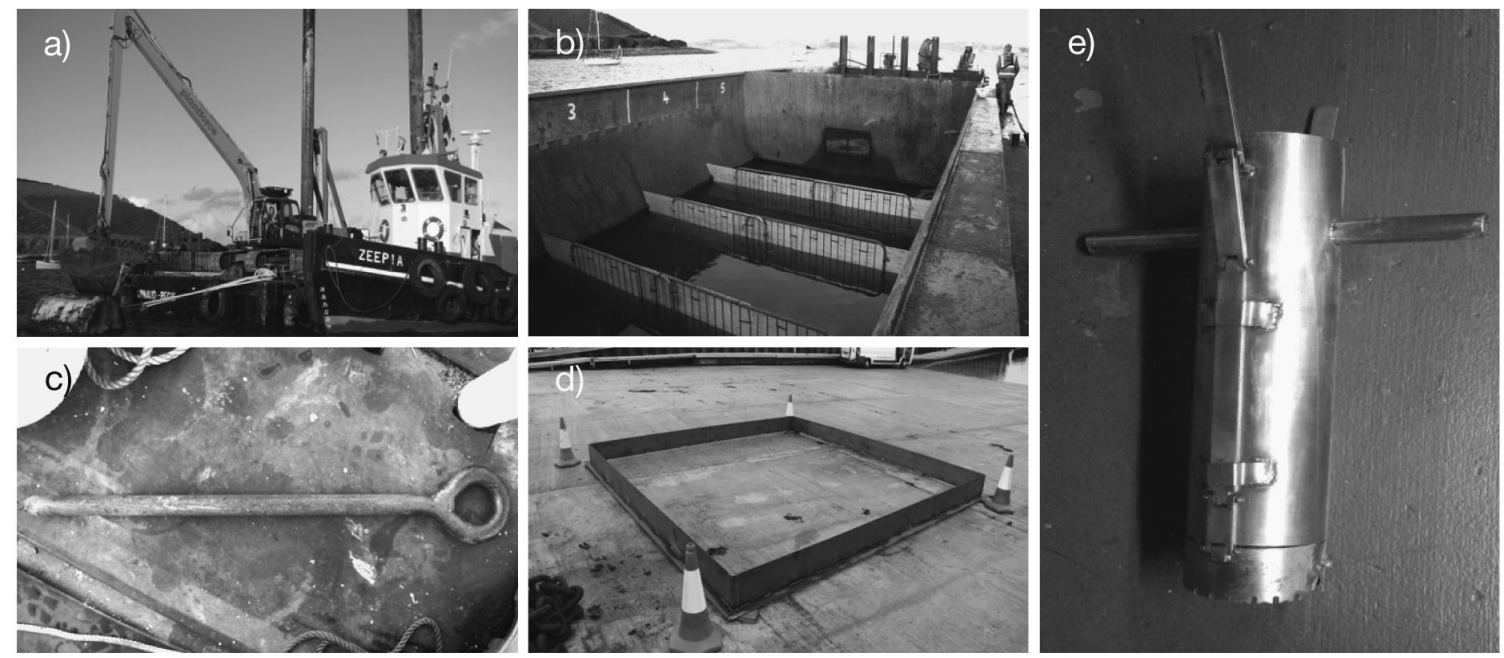

Fig. 3. Photos from the maerl extraction and re-lay: (a) multipurpose dredging pontoon and tug, (b) hopper barge used to store the maerl for $12 \mathrm{~h}$, (c) $1 \mathrm{~m}$ steel eye-bolt site marker, (d) $5 \mathrm{~m} \times 5 \mathrm{~m}$ steel frame, (e) bespoke maerl corer with retractable serrated jaws 
Particle size analysis

Laser diffraction and sieves were used to measure particle size. Particles $<1 \mathrm{~mm}$ were measured using low-angle laser diffraction, with a Malvern Mastersizer 2000 laser particle sizer (software version 5.6). Two sets of lenses were employed, a $1000 \mathrm{~mm}$ lens for the size range of $4-2000 \mu \mathrm{m}$ and a $45 \mathrm{~mm}$ lens for the size range of $0.1-80 \mu \mathrm{m}$. Samples were dispersed in a $0.1 \%$ sodium hexametaphosphate solution and sonicated for $30 \mathrm{~s}$. The average of 5 runs measured from the $1000 \mathrm{~mm}$ lens data was blended with 1 reading from the $45 \mathrm{~mm}$ lens.

To obtain the dry weight of the larger fractions, $>1 \mathrm{~mm}$ and $<1 \mathrm{~mm}$ sediment was split into 2 beakers and dried in a drying oven set at $60^{\circ} \mathrm{C}$. The dry weight of sediment $<1 \mathrm{~mm}$ was measured once the sediment had fully dried. Sediment fractions $>1 \mathrm{~mm}$ were dried and sieved through Wentworth sieves in half phi ( ) intervals to get the dry weight of each grain size parameter. Laser diffraction data and sieve data were combined and mean grain size calculated.

\section{Maerl structure}

Maerl structure was measured by quantifying the interstitial space in the sediment sample. A $250 \mathrm{ml}$ measuring cylinder was filled with $100 \mathrm{ml}$ of each sample and $100 \mathrm{ml}$ of water and left for $15 \mathrm{~min}$ to allow suspended sediment particles to settle. The new volume was converted into percentage interstitial space available for each sample. For example, if the new volume is $160 \mathrm{ml}$, the sample has $40 \%$ interstitial space, as $40 \mathrm{ml}$ of the water was able to drain through the sample.

\section{Organic content}

Subsamples were placed in pre-weighed crucibles and dried in a drying oven set at $60^{\circ} \mathrm{C}$ for $24 \mathrm{~h}$. The dry weight was recorded before the samples were put in a furnace for combustion at $450^{\circ} \mathrm{C}$ for $4 \mathrm{~h}$. Once cool, the samples were then weighed again to determine the ash-free dry weight and thus calculate organic content through loss on ignition.

\section{Infauna sample processing}

In the laboratory, samples were sieved through a $0.5 \mathrm{~mm}$ Endecotts sieve under a fume hood. Speci- mens were picked and stored in glass vials filled with $70 \%$ ethanol. Specimens were identified to the lowest taxonomic level possible using a Wild Heerbrugg M3 dissection microscope and a Nikon compound microscope. The abundance of each species in each sample was recorded, as was the biomass (blotted wet weight) of each phylum. Identification and enumeration of taxa were undertaken by expert taxonomists at Marine Ecological Surveys Ltd.

\section{Data analyses}

Differences in response variables were examined with permutational multivariate ANOVA (PERMANOVA) using the software package PRIMER v6.0 (Anderson 2001, Clarke \& Warwick 2001). Significance was accepted at $\mathrm{p}<0.05$.

\section{Comparison of dead maerl sites vs. site with live maerl fragments}

One site (Site 6) contained some pieces of live maerl scattered across the seabed surface (Sheehan et al. 2012). To assess whether this site was inherently different to the other sites based on habitat and faunal response variables, multivariate analyses were used to compare the non-dredged plots between sites. Four replicate plots were used for each site: controls at Weeks 0,5 and 44, and the treatment plots at Week 0. Cores were averaged for each plot $(5 \times$ cores for fauna; $3 \times$ cores for sediment variables). The habitat composition (particle size top, particle size bottom, maerl structure top, maerl structure bottom, organic content top, organic content bottom) was compared using a 1factor PERMANOVA between all 6 sites. Pairwise tests in PERMANOVA were used to determine statistically significant differences between sites, and nonmetric multidimensional scaling (nMDS) used to visualise any relative differences in habitat composition. This analysis was then repeated for composition of the associated infaunal assemblages.

\section{Comparison of conditions over time}

A 2-factor design was used to compare each response variable between time and condition. Both factors were fixed. Time had 3 levels (Week 0, Week 5 and Week 44), and condition had 2 levels (treatment vs. control) with 6 replicate sites. Cores were averaged for each plot $(5 \times$ cores for fauna; $3 \times$ cores 
for habitat variables). Univariate measures (fauna: number of taxa, abundance, key phylum biomass for Mollusca, Arthropoda, Echinodermata and Annelida; habitat: particle size top, particle size bottom, maerl structure top, maerl structure bottom, organic content top, organic content bottom) were $\log (x+1)$ transformed and similarities were based on Euclidean distances.

Multivariate assemblage composition data were square root transformed. As joint species absences were important to consider between conditions, data were 'zero-adjusted' by adding a dummy value of 0.1 (Clarke et al. 2006). Without the dummy value, BrayCurtis would not consider samples equally devoid of species as similar, such as species which were lost as a result of the trial.

Only significant differences between the Time $x$ Condition interaction were further interpreted using pairwise tests in PERMANOVA in order to assess impact and recovery trends over time. Observed differences between condition in the absence of a Time $\times$ Condition interaction could be interpreted as spatial differences. Observed differences between time in the absence of a Time $\times$ Condition interaction were also not further interpreted, as there were no prior hypotheses regarding seasonal change over time that were not a result of the trial.

Mean and standard errors are reported thoughout.

\section{RESULTS}

\section{Habitat}

Comparison of dead maerl sites vs. site with live maerl fragments

A comparison of the non-dredge plots showed that, while habitat composition did vary between sites ( $\mathrm{p}<0.05$; Table 1), only Sites 1 and 5, and Sites 1 and 6 (both $\mathrm{p}<0.05$; Table 1) were significantly different to each other. Site 6 was not significantly different from Site 2, 3, 4 or 5. Therefore, for the habitat analyses, Site 6 was included with the other sites.

\section{Particle size analysis}

There was no Time $\times$ Condition interaction in the top half of cores ( $p>0.05$; Table 2, Fig. 4a). For the bottom half, however, there was a Time $\times$ Condition interaction $(\mathrm{p}<0.05$; Table 2$)$. The mean particle size was similar between conditions in Week $0(\mathrm{p}=0.60$; treatment: $1611.41 \pm 254.31 \mu \mathrm{m}$, control: $1783.99 \pm$ $255.38 \mu \mathrm{m}$ ) and significantly greater in the treatment than the control in Week 5 ( p < 0.05; treatment: $2828.55 \pm 304.20 \mu \mathrm{m}$, control: $1320.28 \pm 137.44 \mu \mathrm{m})$ and Week 44 ( $\mathrm{p}<0.05$; treatment: $2836.76 \pm$ $346.15 \mu \mathrm{m}$, control: $1535.48 \pm 121.63 \mu \mathrm{m}$ ) (Table 2, Fig. 4b).

\section{Maerl structure}

In the top half of samples, there was no Time $x$ Condition interaction ( $\mathrm{p}>0.05$; Table 2, Fig. 4c). There was, however, a significant Time $\times$ Condition interaction in the bottom half of cores $(p<0.05$; Table 2). Pairwise tests showed that while conditions were similar in Week $0(\mathrm{p}=0.57$; treatment: $31.89 \pm$ $2.29 \%$, control: $29.56 \pm 3.20 \%$ ), interstitial space was greater in the treatment than the control in Week 5 ( $\mathrm{p}<0.05$; treatment: $40.33 \pm 2.05 \%$, control: $24.67 \pm$ $1.53 \%$ ) and Week 44 ( $\mathrm{p}<0.05$; treatment: $43.78 \pm$ $2.26 \%$, control: $25.61 \pm 1.88 \%$ ) (Table 2, Fig. $4 \mathrm{~d}$ ).

\section{Organic content}

There was no Time $\times$ Condition interaction in either the top or bottom half of the sediment (both $\mathrm{p}>0.05$ ) (Table S1 in the Supplement at www.int-res.com/ articles/suppl/m535p117_supp.pdf).

\section{Fauna}

A total of 41172 individuals were found in the infauna samples. These were identified to 347 taxa from 16 phyla (see Table S2 in the Supplement for

Table 1. PERMANOVA tests to compare habitat and infauna variables between non-dredge plots from each site and pairwise tests for factor Site. Bold: significant result $(p<0.05)$

\begin{tabular}{|c|c|c|c|c|c|c|c|}
\hline \multirow{2}{*}{ Source } & \multirow[t]{2}{*}{$\mathrm{df}$} & \multicolumn{3}{|c|}{ - Habitat } & \multicolumn{3}{|c|}{ - Infauna } \\
\hline & & MS & $F$ & $\mathrm{p}$ & MS & $F$ & $\mathrm{p}$ \\
\hline Site & 5 & 10.06 & 2.06 & $<0.05$ & 1319.5 & 2.12 & $<0.05$ \\
\hline Residual & 18 & 4.87 & & & 657.67 & & \\
\hline Total & 23 & & & & & & \\
\hline \multirow{2}{*}{\multicolumn{2}{|c|}{ Site pairwise }} & \multicolumn{6}{|c|}{ Sites significantly different from each other } \\
\hline & & \multicolumn{3}{|c|}{1,5 and 1,6} & \multicolumn{3}{|c|}{$\begin{array}{c}1,2 ; 1,4 ; 1,5 ; 1,6 ; \\
2,4 ; 2,5 ; 2,6 ; 3,5 ; \\
3,6 ; 4,5 ; 4,6 \text { and } 5,6\end{array}$} \\
\hline
\end{tabular}


Table 2. PERMANOVA to test differences of habitat response variables between Time (Week 0, 5 and 44) and Condition (Treatment or Control). Bold: significant result $(\mathrm{p}<0.05)$; n.a.: not applicable

\begin{tabular}{|c|c|c|c|c|c|c|c|}
\hline \multirow{2}{*}{$\begin{array}{l}\text { Particle size } \\
\text { Source }\end{array}$} & \multirow[t]{2}{*}{$\mathrm{df}$} & \multicolumn{3}{|c|}{ - Top } & \multicolumn{3}{|c|}{ - Bottom } \\
\hline & & MS & $F$ & $\mathrm{p}$ & MS & $F$ & $\mathrm{p}$ \\
\hline Time & 2 & 0.26 & 2.84 & 0.08 & 0.18 & 1.89 & 0.17 \\
\hline Condition & 1 & 1.05 & 11.35 & $<0.05$ & 1.51 & 15.84 & $<0.05$ \\
\hline Time $\times$ Condition & 2 & 0.13 & 1.40 & 0.26 & 0.66 & 6.94 & $<0.05$ \\
\hline Residual & 30 & 0.1 & & & & & \\
\hline Total & 35 & & & & & & \\
\hline \multicolumn{2}{|c|}{ Time $\times$ Condition pairwise } & Time & $\mathrm{p}$ & & Time & $\mathrm{p}$ & \\
\hline \multirow{3}{*}{\multicolumn{2}{|c|}{ Treatment vs. Control }} & 0 & n.a. & & 0 & 0.60 & \\
\hline & & 5 & n.a. & & 5 & $<0.05$ & \\
\hline & & 44 & n.a. & & 44 & $<0.05$ & \\
\hline \multirow{2}{*}{$\begin{array}{l}\text { Maerl structure } \\
\text { Source }\end{array}$} & \multirow[t]{2}{*}{$\mathrm{df}$} & \multicolumn{3}{|c|}{ - Top } & \multicolumn{3}{|c|}{ Bottom } \\
\hline & & MS & $F$ & $\mathrm{p}$ & MS & $F$ & $\mathrm{p}$ \\
\hline Time & 2 & 0.05 & 0.38 & 0.74 & 0.03 & 0.18 & 0.36 \\
\hline Condition & 1 & 0.71 & 5.05 & $<0.05$ & 1.17 & 38.72 & $<0.05$ \\
\hline Time $\times$ Condition & 2 & 0.39 & 2.77 & 0.06 & 0.1 & 6.10 & $<0.05$ \\
\hline Residual & 30 & 0.14 & & & 0.03 & & \\
\hline Total & 35 & & & & & & \\
\hline \multicolumn{2}{|c|}{ Time $\times$ Condition pairwise } & Time & $\mathrm{p}$ & & Time & $\mathrm{p}$ & \\
\hline \multirow{3}{*}{\multicolumn{2}{|c|}{ Treatment vs. Control }} & 0 & n.a. & & 0 & 0.57 & \\
\hline & & 5 & n.a. & & 5 & $<0.05$ & \\
\hline & & 44 & n.a. & & 44 & $<0.05$ & \\
\hline
\end{tabular}

species list), including 151 Annelida, 91 Arthropoda, 64 Mollusca and 14 Echinodermata taxa.

\section{Comparison of dead maerl sites vs. site with live maerl fragments}

A preliminary comparison of the assemblage composition between non-dredge plots showed that most sites were different to each other $(p<0.05$; Table 1). Only 3 out of 15 site combinations were not significantly different to each other (Sites 1 and 3, 2 and 3, 3 and 4: p > 0.05). Site 6 assemblage composition was not distinctly different to the other inter-site differences and was therefore included in the subsequent faunal analyses

\section{Number of taxa}

There was a significant Time $\times$ Condition interaction ( $p<0.05$; Table 3 ). There was no significant difference between treatment and control at Week 0 ( $\mathrm{p}>0.05$; Table 3). However, following the trial dredge, in Week 5 there were significantly fewer taxa in the treatment compared to the control $(\mathrm{p}<0.05$; treatment: $53.66 \pm 5.96$ per core; control: $94.17 \pm 2.43$ per core) (Table 3, Fig. 5a). By Week 44, the number of taxa in the treatment had increased (Fig. 5a) and there was no significant difference between conditions ( $p>0.05$; Table 3 ).

\section{Abundance}

There was a Time $\times$ Condition interaction ( $p<0.05$; Table 3 ) similar to the number of taxa. There was no significant difference in abundance between conditions at Week 0 or 44 (both p > 0.05; Table 3) and again, following the trial dredge, abundance was significantly lower in the treatment than the control in Week 5 (treatment: $155.1 \pm 24.18$ ind. per core, control: $281.8 \pm 24.74$ ind. per core; Fig. 5b) ( $<<0.05$; Table 3).

\section{Key phylum biomass}

The biomasses of the phyla Mollusca, Arthropoda or Echinodermata did not significantly change as a result of the experiment (all p > 0.05) (Table S1 in the Supplement). However, there was a Time $\times$ Condition interaction for Annelida ( $\mathrm{p}<0.05$; Table 3). There was no significant difference between conditions at Week 0 ( $\mathrm{p}>0.05$; Table 3), but at both Week 5 and 44, the Annelida biomass was significantly lower in the treatment than the control (both $\mathrm{p}<0.05$; Week 5: treatment: $0.06 \pm 0.01 \mathrm{~g}$ per core, control: $0.53 \pm 0.13 \mathrm{~g}$ per core; Week 44: treatment: $0.16 \pm 0.02 \mathrm{~g}$ per core, control: $0.39 \pm 0.05 \mathrm{~g}$ per core) (Table 3, Fig. $5 \mathrm{c}$ ).

\section{Assemblage composition}

There was a significant Time $\times$ Condition interaction for assemblage composition ( $p<0.05$; Table 3$)$. There was no significant difference between conditions in Week 0 ( $\mathrm{p}>0.05$; Table 3); however, in Week 5, following the trial dredge, there was a significant difference between treatment and control $(\mathrm{p}<0.05$; Table 3). By Week 44, there was no longer a 

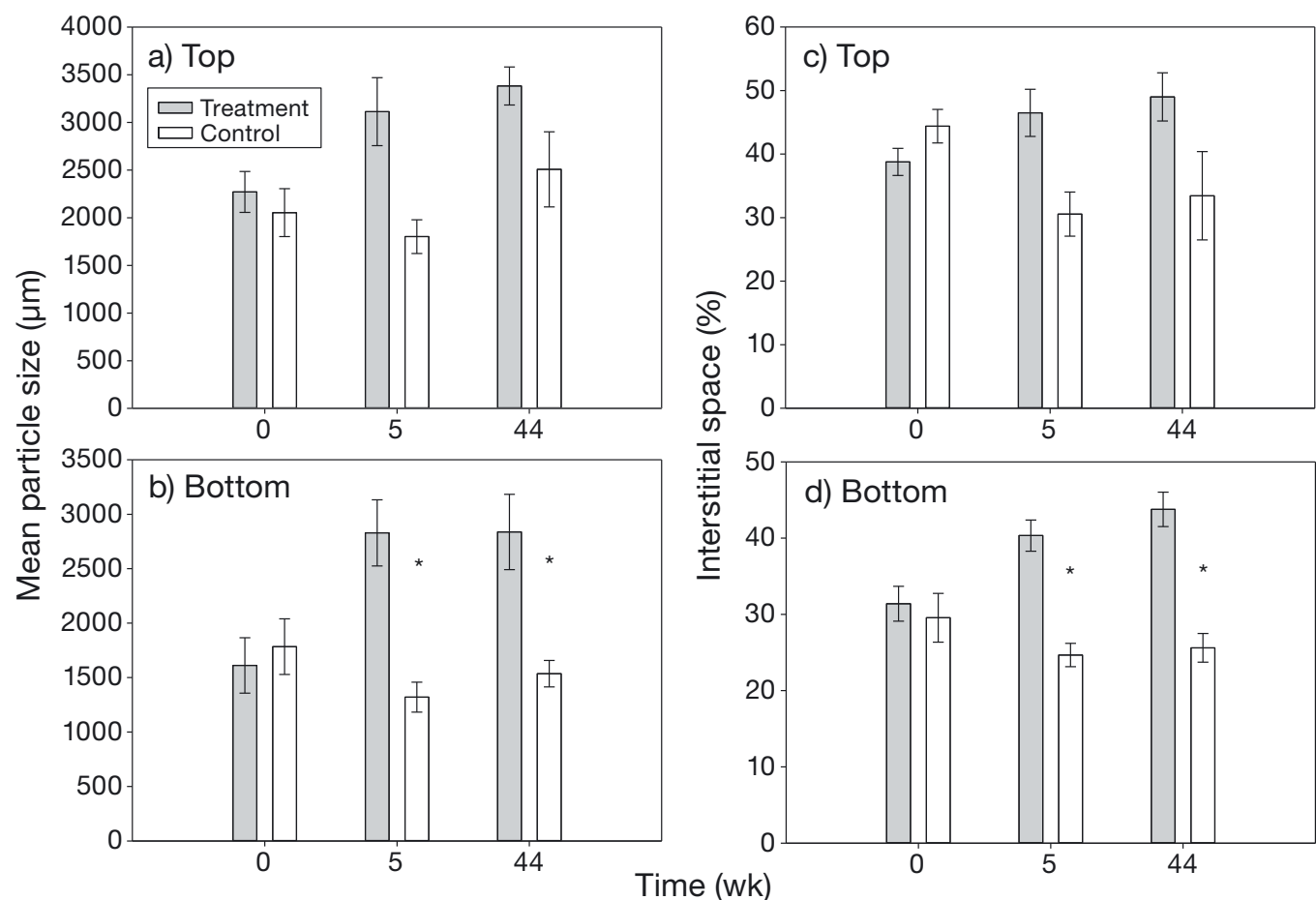

Fig. 4. Habitat response variables: (a) and (b) show mean $( \pm \mathrm{SE})$ particle size for the top and bottom half of the cored sample respectively, (c) and (d) similarly show \% interstitial space within the maerl matrix. Time is number of weeks from trial dredge: 0 (a week before), 5 and 44 wk after. *Significant differences $(\mathrm{p}<0.05)$

Table 3. Faunal assemblage analysis. PERMANOVA for infaunal taxa measures in response to the fixed factors Time (Week 0,5 and 44) and Condition (Treatment or Control). Bold: significant result $(p<0.05)$

\begin{tabular}{|c|c|c|c|c|c|c|c|}
\hline \multirow{2}{*}{ Source } & \multirow[t]{2}{*}{$\mathrm{df}$} & \multicolumn{3}{|c|}{ Number of taxa -} & \multicolumn{3}{|c|}{-Abundance - } \\
\hline & & MS & $F$ & $\mathrm{p}$ & MS & $F$ & $\mathrm{p}$ \\
\hline Time $(\mathrm{T})$ & 2 & 0.38 & 15.69 & $<0.05$ & $9.85 \times 10^{-2}$ & 0.93 & 0.40 \\
\hline Condition (C) & 1 & 0.25 & 10.20 & $<0.05$ & $5.91 \times 10^{-3}$ & $5.60 \times 10^{-2}$ & $2 \quad 0.82$ \\
\hline $\mathrm{T} \times \mathrm{C}$ & 2 & 0.39 & 16.04 & $<0.05$ & 0.87 & 8.27 & $<0.05$ \\
\hline Residual & 30 & $2.42 \times 10^{-2}$ & & & 0.11 & & \\
\hline Total & 35 & & & & & & \\
\hline $\mathrm{T} \times \mathrm{C}$ pairwise & & Time & $\mathrm{p}$ & & Time & $\mathrm{p}$ & \\
\hline \multirow{3}{*}{\multicolumn{2}{|c|}{ Treatment vs. Control }} & 0 & 0.30 & & 0 & 0.15 & \\
\hline & & 5 & $<0.05$ & & 5 & $<0.05$ & \\
\hline & & 44 & 0.93 & & 44 & 0.12 & \\
\hline \multirow[t]{2}{*}{ Source } & \multirow[t]{2}{*}{ df } & —Anneli & da biom & hass - & \multicolumn{3}{|c|}{ Assemblage composition } \\
\hline & & MS & $F$ & $\mathrm{p}$ & MS & $F$ & $\mathrm{p}$ \\
\hline Time $(\mathrm{T})$ & 2 & $1.42 \times 10^{-2}$ & 1.39 & 0.27 & 3316.4 & 4.67 & $<0.05$ \\
\hline Condition (C) & 1 & 0.27 & 26.08 & $<0.05$ & 2176.8 & 3.06 & $<0.05$ \\
\hline $\mathrm{T} \times \mathrm{C}$ & 2 & 0.11 & 10.79 & $<0.05$ & 1955.3 & 2.75 & $<0.05$ \\
\hline Residual & 30 & $1.02 \times 10^{-2}$ & & & 710.57 & & \\
\hline Total & 35 & & & & & & \\
\hline $\mathrm{T} \times \mathrm{C}$ pairwise & & Time & $\mathrm{p}$ & & Time & $\mathrm{p}$ & \\
\hline \multirow{3}{*}{\multicolumn{2}{|c|}{ Treatment vs. Control }} & 0 & 0.62 & & 0 & 0.80 & \\
\hline & & 5 & $<0.05$ & & 5 & $<0.05$ & \\
\hline & & 44 & $<0.05$ & & 44 & 0.11 & \\
\hline
\end{tabular}

significant difference between conditions ( $p>0.05$; Table 3$)$. The nMDS shows that the control samples are similar to each other across all weeks; on the other hand, the treatment samples were more dissimilar to each other, particularly in Week 5 (Fig. 6).

\section{DISCUSSION}

Testing the resilience of infauna to removal and re-laying of maerl habitat as a mitigation method to preserve a protected habitat showed that, overall, approximately half of the assemblage was not resistant to the process, but the measured community showed signs of recovery within $44 \mathrm{wk}$. While polychaete biomass did not recover over the time period of the study, overall the responses of the infaunal community to the trial were comparatively consistent: the majority 

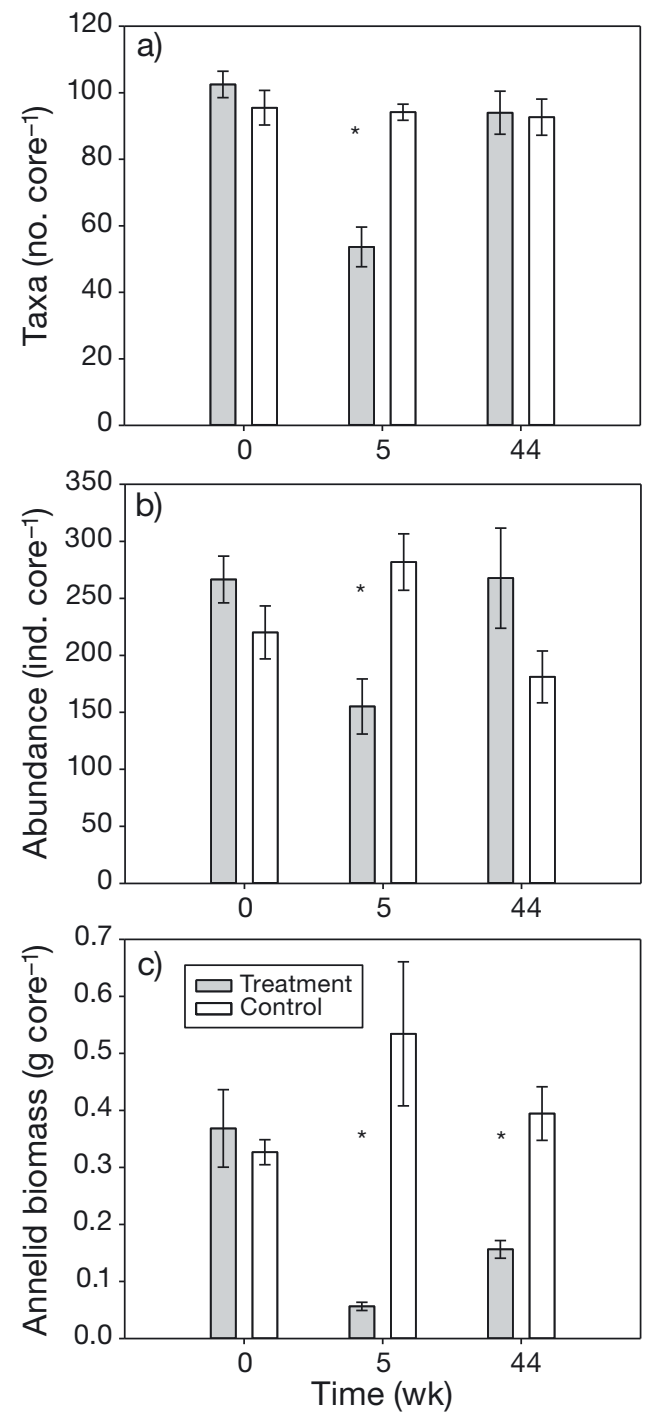

Fig. 5. (a) Number of taxa per core (mean \pm SE), (b) abundance (number of organisms) per core (mean \pm SE), (c) Annelida biomass per core (mean $\pm \mathrm{SE}$ ). Time is number of weeks from trial dredge: 0 (a week before), 5 and $44 \mathrm{wk}$ after. ${ }^{*}$ Significant differences $(\mathrm{p}<0.05)$

of measures showing a significant decrease in Week 5 , but then a recovery to pre-trial levels by Week 44 . This was despite changes occurring in the habitat, where there was a loss of fine material from the maerl matrix; any significant changes were generally most apparent in the bottom half of the sediment layer $(\sim 11-25 \mathrm{~cm})$. The habitat structure and associated invertebrate assemblage within the site containing live maerl fragments were not notably more distinct than the dead maerl sites and the assemblage did not respond any differently from the other sites.

The major changes to the habitat structure resulted from a loss of fine sediment during the extraction and

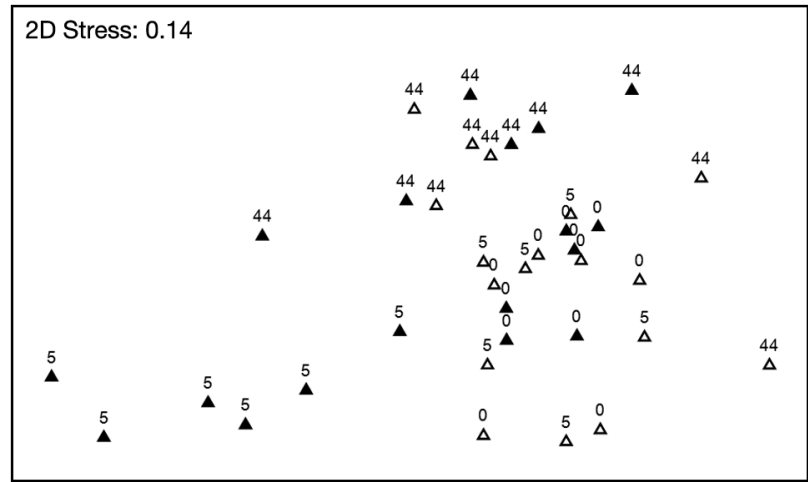

Fig. 6. nMDS showing the similarity in assemblage composition between conditions: treatment (shaded triangles) and control (open triangles) over time (number of weeks since trial dredge: 0, 5 and 44)

re-laying process, causing an increase in mean particle size within the treatment condition. In terms of the Time $\times$ Condition interaction, this was only significant for the bottom half of the core, but still remained after $44 \mathrm{wk}$. There was no such interaction for organic content. The maerl structure seemed to remain relatively intact; there was an increase in percentage interstitial space within the treatment condition (significant interaction only within the lower half of the core), suggesting the gaps between maerl fragments were maintained, the increase in space due to the reduction in fine sediment to fill these spaces. It is likely that, within the dynamic context of an outer estuary setting, further fine sediment will be deposited and thus replenish the lost material within the maerl matrix.

Number of taxa and abundance (number of individuals) followed the same trend. Treatment and control conditions were not significantly different to each other at Weeks 0 and 44, but were significantly different at Week 5. This indicates a loss of fauna due to the extraction and re-laying process, but that diversity and abundance had returned to pre-trial levels by Week 44. Relative to controls at Week 5, the fauna loss equated to $44 \%$ of diversity and $45 \%$ of abundance, suggesting $>50 \%$ of organisms potentially survived the process or very quickly recolonised. There were, however, no significant changes to the overall biomass of Mollusca, Crustacea and Echinodermata across the study, perhaps indicating that the larger individuals of these groups remained present at 5 and $44 \mathrm{wk}$, potentially protected by the maerl structure within the holding barge, whereas smaller organisms were more likely to be washed out with the fine sediment during the re-laying process. Addi- 
tionally, Hinojosa-Arango et al. (2009) reported that migration of large molluscs and crustaceans was common during their maerl stability experiments. The biomass of Annelida in the present study did change, however, with significant differences between treatment and control conditions in Weeks 5 and 44 following the trial dredge, indicating that this phylum may be more vulnerable to the mechanical effects of the trial process (e.g. Thrush et al. 1995). This is perhaps unsurprising given that the other 3 phyla have forms of hard body parts to give some protection; Hauton et al. (2003) reported intact bivalves surviving experimental hydraulic dredging within maerl habitats. This change in biomass was not reflected in the overall abundance or diversity of the annelid fauna, suggesting recruitment of smaller individuals.

There was also a significant difference between treatment and controls in the assemblage composition at Week 5, reflecting the diversity and abundance changes. However, there were no differences between assemblage composition at Weeks 0 and 44, indicating that the recovery of diversity and abundance was not due to the colonisation of different (perhaps ephemeral) taxa, but a return to a community that was similar to that existing pre-trial. For this trial, it can therefore be stated that the mechanical stresses associated with extraction and re-laying removed approximately half the fauna, but that all measures of the assemblage recovered by Week 44, except annelid biomass.

As stated previously, ecosystem resilience has 2 aspects (Kotta et al. 2008): capacity to tolerate disturbance (sensitivity or resistance) and ability to rebuild (recovery) when necessary. Resistance can be viewed as the ability of an ecosystem to absorb disturbance before changing its structure, while recovery relates to the rate of return to a steady state following perturbation (Pimm 1984). The present experimental trial therefore assessed both aspects of resilience: how the mechanical disturbance of removing and re-laying the maerl impacted the habitat and associated assemblage (resistance), and whether the habitat was subsequently suitable for assemblage recovery. The maerl-associated assemblage was surprisingly resistant, with over half the diversity and abundance appearing to survive the removal and re-laying process. Similarly, the dead maerl structure in the present study was maintained, indicating a capacity to physically survive the process without the maerl fragments breaking down further. This is in contrast to other physical impacts, such as from scallop dredging, where biogenic carbonate structures tend to be crushed and compacted (Hall-Spencer \& Moore
2000, Kamenos et al. 2003), suggesting the dredging method used in this study maintained the integrity of the physical habitat aiding invertebrate survival. This maintenance of structural complexity is also a necessity for successful potential resettlement and recruitment of the fauna (Kamenos et al. 2004b, Howarth et al. 2011), with a more complex maerl matrix, with a subsequently larger interstitial volume, supporting greater numbers of organisms (Steller et al. 2003). The recovery of faunal diversity and abundance within treatment plots in the present study after 44 wk suggests that the successful maintenance of structural habitat had occurred, there being a clear connection between such benthic physical parameters and the associated infauna (Warwick \& Uncles 1980), but multivariate analysis also demonstrated that the composition of this recovery assemblage was not statistically different from controls. Two mechanisms of enabling recovery of lost species are possible (Whitlatch et al. 1998): migration of organisms (adults and juveniles) from surrounding habitats, or recruitment of new individuals (larvae/juveniles) from the water column. Whilst adult movement will be more effective into small disturbed patches, this has little influence over population recovery speed (Whitlatch et al. 1998), and thus the speed of recovery, and recovery of large disturbed areas, is more dependent on post-settlement juveniles. Our result that annelid biomass remained low, yet abundance and diversity had recovered, suggests the primary recovery route of this sedentary group at least is through recruitment of a new generation rather than lateral migration in from surrounding habitats, although Hinojosa-Arango et al. (2009) recorded the movement of sedentary bivalves into their manipulated maerl experiments.

Whilst Hall-Spencer \& Moore (2000) reported that recovery of live maerl following scallop dredging was not evident after $4 \mathrm{yr}$, the speed of recovery of associated macrobenthos in this study (at most $300 \mathrm{~d}$ ) fits with other experiments on soft sediment systems. Similar-sized intertidal sand disturbance plots recovered in either 64 or 208 d depending on physical disturbance severity (Dernie et al. 2003a), while a metaanalysis of fishing impact on subtidal benthos (Collie et al. 2000) reported recovery occurring between 100 and 500 d. Recovery speed also appears to be substrate-dependent, with coarser sediments recovering quicker than those with high silt fractions (Dernie et al. 2003b). Assemblages associated with dead maerl habitats are therefore responding more similarly to those in other sedimentary benthic systems than those fully composed of living maerl thalli. 
This study has demonstrated for the first time that a mitigation method to protect dead maerl habitat whilst allowing dredging activity may well be feasible. The top $0.3 \mathrm{~m}$ of the seabed was removed, stored at the surface and returned to the sea floor, altering the physical structure through the, probably temporary, loss of fine materials. Over half the associated organisms survived the mechanical process, and within $300 \mathrm{~d}$, the assemblages within experimental treatments were indistinguishable from controls. This study has positive implications for potentially protecting such valuable benthic habitats from development. It should be emphasised, however, that this study removed the top layer of dead maerl habitat; therefore these results should not be extrapolated to live maerl habitat examples. The representativeness of this experiment to a deeper, full-scale capital dredge should now be assessed.

Acknowledgements. We acknowledge the funding and support provided by Falmouth Harbour Commission. We thank the following people and companies for their help that enabled us to undertake this challenging experiment: Leon Kemp, John Walker, Richard Hartley, Luke Holmes, Falmouth Divers Ltd, GPS Marine and Marine Ecological Surveys Ltd. We also thank the MMO Independent Scientific Advisory Panel, who provided advice throughout the study.

\section{LITERATURE CITED}

Anderson MO (2001) Permutation tests for univariate or multivariate analysis of variance and regression. Can J Fish Aquat Sci 58:629-639

Anderson P (2003) Habitat translocation - a best practice guide (CIRIA C600). Construction Industry \& Research Information Association, London

Barbera C, Bordehore C, Borg JA, Glemarec M and others (2003) Conservation and management of northeast Atlantic and Mediterranean maerl beds. Aquat Conserv Mar Freshw Ecosyst 13(Suppl 1):S65-S76

BIOMAERL Team (1999) Final report, BIOMAERL project. EC Contract No. MAS3-CT95-0020. University Marine Biological Station, Millport

Bolam SG, Rees HL, Somerfield P, Smith R and others (2006) Ecological consequences of dredged material disposal in the marine environment: a holistic assessment of activities around the England and Wales coastline. Mar Pollut Bull 52:415-426

Bosence DWJ (1979) Live and dead faunas from coralline algal gravels, Co. Galway. Palaeontology 22:449-478

$>$ Box J (2003) Critical factors and evaluation criteria for habitat translocation. J Environ Plan Manage 46:839-856

Clarke KR, Warwick RM (2001) Change in marine communities: an approach to statistical analysis and interpretation. PRIMER-E, Plymouth

> Clarke KR, Somerfield PJ, Chapman MG (2006) On resemblance measures for ecological studies, including taxonomic dissimilarities and a zero-adjusted Bray-Curtis coefficient for denuded assemblages. J Exp Mar Biol Ecol $330: 55-80$
Collie JS, Hall SJ, Kaiser MJ, Poiner IR (2000) A quantitative analysis of fishing impacts on shelf-sea benthos. J Anim Ecol 69:785-799

Cooper KM, Eggleton JD, Vize SJ, Vanstaen K and others (2005) Assessment of the re-habilitation of the seabed following marine aggregate dredging - part II. Sci Ser Tech Rep 130. Centre for Environment, Fisheries and Aquaculture Science (CEFAS), Lowestoft

Council of the European Union (1992) Council Directive 92/43/EEC of 21 May 1992 on the conservation of natural habitats and of wild fauna and flora. Off J Eur Comm L 206:7-49

> De Grave S, Whitaker A (1999) Benthic community readjustment following dredging of a muddy-maerl matrix. Mar Pollut Bull 38:102-108

Deeble M, Stone V (1985) A port that could threaten marine life in England's Fal Estuary. Oryx 19:74-78

Dernie KM, Kaiser MJ, Richardson EA, Warwick RM (2003a) Recovery of soft sediment communities and habitats following physical disturbance. J Exp Mar Biol Ecol 285-286:415-434

Dernie KM, Kaiser MJ, Warwick RM (2003b) Recovery rates of benthic communities following physical disturbance. J Anim Ecol 72:1043-1056

Griffith B, Scott JM, Carpenter JW, Reed C (1989) Translocation as a species conservation tool: status and strategy. Science 245:477-480

Hall-Spencer J (1998) Conservation issues relating to maerl beds as habitats for molluscs. J Conchol Spec Publ 2: 271-285

Hall-Spencer JM, Moore PG (2000) Scallop dredging has profound, long-term impacts on maerl habitats. ICES J Mar Sci 57:1407-1415

Hauton C, Hall-Spencer JM, Moore PG (2003) An experimental study of the ecological impacts of hydraulic bivalve dredging on maerl. ICES J Mar Sci 60:381-392

Hinojosa-Arango G, Maggs CA, Johnson MP (2009) Like a rolling stone: the mobility of maerl (Corallinaceae) and the neutrality of the associated assemblages. Ecology 90: $517-528$

Hodgson JG (1989) Selecting and managing plant materials used in habitat construction. In: Buckley GP (ed) Biological habitat reconstruction. Belhaven Press, London, p 45-67

Howarth LM, Wood HL, Turner AP, Beukers-Stewart BD (2011) Complex habitat boosts scallop recruitment in a fully protected marine reserve. Mar Biol 158:1767-1780

Jackson CM, Kamenos NA, Moore PG, Young M (2004) Meiofaunal bivalves in maerl and other substrata: their diversity and community structure. Ophelia 58: 48-60

Kamenos NA, Moore PG, Hall-Spencer JM (2003) Substratum heterogeneity of dredged vs. un-dredged maerl ground. J Mar Biol Assoc UK 83:411-413

Kamenos NA, Moore PG, Hall-Spencer JM (2004a) Smallscale distribution of juvenile gadoids in shallow inshore waters; what role does maërl play? ICES J Mar Sci 61: 422-429

Kamenos NA, Moore PG, Hall-Spencer JM (2004b) Attachment of the juvenile queen scallop (Aequipecten opercularis (L.)) to maërl in mesocosm conditions; juvenile habitat selection. J Exp Mar Biol Ecol 306:139-155

Kotta J, Aps R, Herkül K (2008) Predicting ecological resilience of marine benthic communities facing a high risk of oil spills. In: Brebbia CA (ed) Environmental problems in 
coastal regions VII. WIT Press, Wessex Institute of Technology, Southampton, p 101-110

McCauley JE, Parr RA, Hancock DR (1977) Benthic infauna and maintenance dredging: a case study. Water Res 11: 233-242

Nunn J (1992) The molluscan fauna associated with maerl. Conchol Newsl 125:161-167

OSPAR (2010) Background document for maerl beds. OSPAR Commission, London. http://qsr2010.ospar.org/media/ assessments/Species/P00491_maerl.pdf (accessed 13 Nov 2014)

Peña V, Bárbara I, Grall J, Maggs CA, Hall-Spencer JM (2014) The diversity of seaweeds on maerl in the NE Atlantic. Mar Biodiversity 44:533-551

Pimm SL (1984) The complexity and stability of ecosystems. Nature 307:321-326

Sheehan EV, Stevens TF, Attrill MJ (2010) A quantitative, non-destructive methodology for habitat characterisation and benthic monitoring at offshore renewable energy developments. PLoS ONE 5:e14461

Sheehan EV, Cousens S, Attrill MJ (2012) The location and extent of live and dead maerl beds in Falmouth Harbour, southwest UK. Plymouth University Marine Institute report to Falmouth Harbour Commissioners

Sheehan EV, Bridger D, Attrill MJ (2015) The ecosystem service value of living versus dead biogenic reef. Estuar Coast Shelf Sci 154:248-254

Sheller FJ, Fagan WF, Unmack PJ (2006) Using survival analysis to study translocation success in the Gila topminnow (Poeciliopsis occidentalis). Ecol Appl 16:1771-1784

Editorial responsibility: Christine Paetzold, Oldendorf/Luhe, Germany
Steller DL, Riosmena-Rodríguez R, Foster MS, Roberts CA (2003) Rhodolith bed diversity in the Gulf of California: the importance of rhodolith structure and consequences of disturbance. Aquat Conserv Mar Freshw Ecosyst 13(Suppl 1):S5-S20

Thrush SF, Dayton PK (2002) Disturbance to marine benthic habitats by trawling and dredging: implications for marine biodiversity. Annu Rev Ecol Syst 33:449-473

Thrush SF, Hewitt JE, Cummings VJ, Dayton PK (1995) The impact of habitat disturbance by scallop dredging on marine benthic communities: what can be predicted from the results of experiments? Mar Ecol Prog Ser 129:141-150

UK Biodiversity Group (1999) Maritime species and habitats. Tranche 2 Action Plans, Vol 5. English Nature, Peterborough

- Warwick RM, Uncles RJ (1980) Distribution of benthic macrofauna associations in the Bristol Channel in relation to tidal stress. Mar Ecol Prog Ser 3:97-103

Whitlatch RB, Lohrer AM, Thrush SF, Pridmore RD, Hewitt JE, Cummings VJ, Zajac RN (1998) Scale-dependent benthic recolonization dynamics: life stage-based dispersal and demographic consequences. Hydrobiologia 375/ 376:217-226

> Wilson S, Blake C, Berges JA, Maggs CA (2004) Environmental tolerances of free- living coralline algae (maerl): implications for European marine conservation. Biol Conserv 120:279-289

Wolf CM, Griffith B, Reed C, Temple SA (1996) Avian and mammalian translocations: update and reanalysis of 1987 survey data. Conserv Biol 10:1142-1154

Submitted: February 11, 2015; Accepted: June 18, 2015 Proofs received from author(s): August 27, 2015 